\title{
Ulko- ja jaloittelutarhojen rakentaminen, ympäristökuormitus ja kustannukset
}

\author{
Jaana Uusi-Kämppä ${ }^{1)}$, Maarit Puumala ${ }^{2)}$, Arja Nykänen ${ }^{3)}$, Arto Huuskonen ${ }^{4)}$ ja Helvi Heinonen- \\ Tanski ${ }^{5}$ \\ 1) MTT, Ympäristöntutkimus, 31600 Jokioinen, jaana.uusi-kamppa@mtt.fi \\ 2) MTT, Maatalousteknologian tutkimus, Vakolantie 55,03400Vihti, maarit.puumala@mtt.fi \\ 3) MTT, Ekologinen tuotanto, Huttulantie 1, 51900 Juva, arja.nykanen@mtt.fi \\ 4) MTT, Pohjois-Pohjanmaan tutkimusasema, Tutkimusasemantie 15, 92400 Ruukki, \\ arto.huuskonen@mtt.fi \\ 5) Kuopion yliopisto, Ympäristötieteiden laitos, PL 1627, 70211 Kuopio, helvi.heinonentanski@uku.fi
}

\section{Johdanto}

Ulkotarhoissa kasvatetaan yleensä lihanautoja ympäri vuoden tai tarhataan emolehmiä talviruokintakaudella. Eläimet syövät ja nukkuvat tarhoissa, joissa on säänsuoja, makuu-, ruokinta- ja juomapaikka. Jaloittelutarhoissa eläimet viipyvät vain joitakin tunteja päivässä. Joissakin tarhoissa houkutellaan lehmät ulos tarjoamalla niille kuivaa heinää tarhassa. Ruokinta- ja makuupaikat ovat yleensä karjasuojassa tai laitumella.

Maa- ja elintarviketalouden tutkimuskeskus (MTT) on tutkinut maapohjaisia ja kiinteäpohjaisia tarhoja sekä niistä aiheutuvaa vesistökuormitusta. Ensimmäiset ulkotarhat tutkimuskäyttöön rakennettiin Tohmajärven emolehmänavetalle vuonna 1995 (Manninen 2001). Jokioisiin valmistui jaloittelutarha MTT:n tutkimuspihaton yhteyteen 1998. Uusia tarhakokeita on aloitettu Pohjois-Pohjanmaan tutkimusasemalla Ruukissa (10 sonnille $10000 \mathrm{~m}^{2}: \mathrm{n}$ metsätarha), Juvalla (100 lehmälle $500 \mathrm{~m}^{2}: \mathrm{n}$ asfalttipohjainen ja $600 \mathrm{~m}^{2}:$ maapohjainen jaloittelutarha) ja Yli-Iissä (45 lehmälle $900 \mathrm{~m}^{2}: \mathrm{n}$ masuunikuonapohjainen jaloittelutarha). Tässä kirjoituksessa tarkastellaan uusista tarhoista saatuja käyttökokemuksia, rakennus- ja käyttökustannuksia sekä tarhoista aiheutuvaa ympäristökuormitusta.

\section{Aineisto ja menetelmät Ulkotarha}

Ulkotarha rakennettiin Ruukissa metsään, jossa nuoren sekametsän (1 ha) puut antoivat sonneille säänsuojaa. Tarha-alueen puusto oli mäntyvaltaista ja seassa oli hieskoivua. Alue aidattiin talvikäyttöön soveltuvalla aitanauhalla. Nauhaan oli sijoitettu johdinpari siten, että se ei vaatinut toimiakseen maadoitusta. Alueen ympäri kiersi kolme nauhaa. Aita oli noin $160 \mathrm{~cm}$ korkea. Eläimille rakennettiin puusta pulpettikattoinen säänsuoja, jonka etuosassa sijaitsevalla ruokintapöydällä oli syöntitilaa 100 cm:ä eläintä kohti. Rakennuksen takaosaan muotoiltiin hiekasta vinokuivikepohja, jonka päälle syntyvä makuualusta oli kooltaan $3,2 \mathrm{~m}^{2} /$ eläin. Alustaa käytettiin kestokuivikepohjan tavoin niin, että maakuupohjalle lisättiin silputtua olkea 2,5-5,0 kg/eläin/päivä. Kuivikkeiden määrä riippui eläinten elopainosta ja sääolosuhteista. Suojarakennuksen etuosaan rakennettiin ontelolaatoista kiinteä betonipohjainen lantakäytävä, jota tarvittaessa voitiin siirtää. Lantakäytävän eteen oli sijoitettu kattamaton ruokintapöytä. Laatalle kerääntynyt lanta puhdistettiin traktorin etukuormaajalla säännöllisesti 2-3 kertaa viikossa. Makuualustan kestokuivikepohja tyhjennettiin kerran vuodessa samalla kun eläinryhmä vaihtui. Eläinten vesihuollon järjestämiseksi tutkimusasemalla kehitettiin metsälaitumille soveltuva juottoautomaatti. Se valmistettiin käytöstä poistetun jääpankkitilasäiliön rakenteista ja soveltaen yksinkertaista uimuritekniikkaa. Siirrettävä 600 l:n automaatti oli halpa, lujarakenteinen, toimintavarma ja hygieeninen. Toimiakseen järjestelmä vaati vain yhden 1,5-3 kW:n valovirralla toimivan lämpövastuksen.

Aidan ja kolmiseinäisen katoksen rakennustarvikkeet saatiin pääosin alueelta raivauksen yhteydessä kaadetuista puista. Valaistukseen tarvittava sähkö tuotiin jatkojohdolla. Tarhaan vedettiin myös maanpäällinen vesijohto, jonka käyttö oli mahdollista vain kesällä. Tarhan rakentamiskustannus oli ilman työtä noin 3300 mk eläinpaikkaa kohti. Ulkotarhojen perustamiskustannuksia voidaan kuitenkin alentaa tilakohtaisin ratkaisuin. Esimerkiksi jos veden ja sähkön saanti alueelle onnistuu ilman merkittäviä rahamenoja ja eläinten sääsuojana voidaan käyttää tilalla jo olemassa olevia rakennuksia, muodostuu suurimmaksi investoinniksi aita. Lihanautojen kasvatuksesta ulkotarhoissa raportoi tarkemmin Huuskonen et al. (2002) tässä julkaisussa.

Tarhasta tulevaa pintavaluntaa kerättiin tarha-alueen alapuolella ojaan. Veden määrä mitattiin Vmittapadolla. Vedenkorkeus luettiin 3 kertaa päivässä. Kevätvalunnan aikana otettiin vesinäytteet 
ravinnemäärityksiä varten 3 kertaa päivässä: aamulla, keskipäivällä ja illalla. Muulloin näyte otettiin kerran päivässä viikonmittaisena kokoomanäytteenä. Näytteenotto alkoi keväällä 2000. Ravinteiden kulkeutumista maassa alaspäin selvitettiin ottamalla maanäytteitä 18 eri kohdasta tarhaa. Jokaisessa pisteessä otettiin näyte kolmesta eri maakerroksesta: $0-5,5-30$ ja $30-60 \mathrm{~cm}$. Maanäytteenotto alkoi syksyllä 1999 ennen sonnien tuomista tarhaan ja sitä jatkettiin seuraavana keväänä ja syksynä.

\section{Jaloittelutarhat}

Juvalla, Etelä-Savossa 100 lehmän pihattonavetan yhteyteen rakennettiin kaksiosainen jaloittelutarha vuonna 2000. Tarhan etuosa, $500 \mathrm{~m}^{2}$, päällystettiin asfalttibetonilla ja takaosaan rakennettiin $600 \mathrm{~m}^{2}: \mathrm{n}$ maapohjainen kuoriketarha. Kiinteäpohjaisen ja maapohjaisen tarhan välissä oli noin $10 \mathrm{~cm}$ :ä korkea asfalttipalle. Tarhan ja pihaton lattian välissä oli noin $20 \mathrm{~cm}$ korkea kynnys estämässä lumen kinostumista oven eteen. Tarhan kaltevuus oli 0,5-1\% valumavesikaivoon päin. Navetan keskivaiheilla sijaitsevan eläinten kulkuoven edessä tarha kallistui 7-8 \% kyseiseen kaivoon päin. Asfalttitarhan yhdelle sivulle oli rakennettu harkoista vajaan metrin korkuinen seinämä, jota vasten lannan kuormaaminen kävi kätevästi traktorin etukuormaajan kauhalla.

Tarhaan muodostuvat vedet valuivat tarhan kulmassa olevaan kaivoon, josta ne pumpattiin uppopumpulla putkea pitkin viereiseen lietteen ilmastussäiliöön. Pumppausputki oli ujutettu suuremman putken sisään, jotta se ei painunut kasaan. Alkuperäisen kurttuputken tilalle vaihdettiin jäykkä putki, koska pumppauksessa esiintyi ongelmia. Tarhasta tulevan veden määrä mitattiin pumppausaikalaskimen avulla. Vedestä otettiin näytteet ravinneanalyysejä varten valunnan mukaan niin, että näytteitä saatiin sekä suuren että pienen valunnan ajalta. Mikrobianalyysejä varten näytteet otettiin 17.5.2001 ja 11.9.2001. Lokakuussa 2001 rakennettiin olki-turve-hakesuodatin, johon asfalttitarhan vedet johdetaan. Suodattimesta vedet pumpataan lietesäiliöön, mutta keväällä 2002 rakennetaan jatkokäsittely, jonka kautta vedet johdetaan ojaan.

Maapohjaisesta tarhasta poistettiin pintamaa ja tilalle ajettiin sorapatja sekä kuorike. Tarha salaojitettiin viiden metrin ojavälillä, niin että salaojaputket tulivat $30 \mathrm{~cm}: n$ syvyisen sorakerroksen pohjalle. Putkien väli oli pieni, koska putkien alle ei haluttu laittaa muovia. Kaikkien tarhasta tulevien vesien oletettiin menevän salaojiin. Vedet johdettiin kaivoon, josta ne pumpattiin pois. Veden määrä mitattiin ja vedestä otettiin näytteet ravinne- ja mikrobianalyysejä varten. Soran päälle laitettiin $25-30 \mathrm{~cm}: n$ kerros kuusen kuoriketta, joka sisälsi pitkiä kuorisuikaleita sekä puunpalasia ja oksia. Kuorike saatiin läheiseltä sahalta. Kuorikepohja puhdistettiin talvella aina lumisateen jälkeen. Tarhan alla, noin metrin syvyydessä, oli myös kuivatussalaoja, josta tuleva vesi analysoitiin aika-ajoin. Tarkoituksena oli selvittää pääseekö ravinteita pohjaveteen.

Koska kyseessä oli luomutila, lehmät jaloittelivat tarhassa päivittäin ympäri vuoden. Lehmien määrää tarhoissa seurattiin 4 kertaa päivässä. Talvella jaloittelu oli 'pakotettua' kahdessa ryhmässä ja kesällä vapaata. Lehmiä oli tarhassa kerrallaan 10-50. Tarhassa oli heinähäkki ulkoruokintaa varten. Varsinkin talvisaikaan lehmät viihtyivät ulkona kauemmin, kun sinne oli järjestetty ruokintaa. Tarhan ympärille oli rakennettu vanhoista sähköpylväistä ja lankuista $120-130 \mathrm{~cm}$ korkea aita. Aita oli liian matala, sillä eläimet pystyivät hyppäämään sen yli talvella, kun tarhaan oli kertynyt lunta.

Kustannusarvion mukaan asfalttitarhan kustannukset olivat $110 \mathrm{mk} / \mathrm{m}^{2}$ ilman tutkimuksesta johtuvia lisäkustannuksia. Kustannusarvion mukaan kuoriketarhan hinnaksi muodostui $50 \mathrm{mk} / \mathrm{m}^{2}$.

Yli-Iihin rakennettiin 45 lypsylehmälle noin $900 \mathrm{~m}^{2}:$ n suuruinen jyräbetonitarha, jonka runkoaineena oli masuunikuona. Pohjarakenne tehtiin granulista, masuunikuonan isohko rakeisesta lajitteesta. Jyräbetonin kerrospaksuus oli noin $10 \mathrm{~cm}$ ja granulin noin $20 \mathrm{~cm}$. Tarha aidattiin $150 \mathrm{~cm}$ korkealla aidalla, jonka pystytolppina käytettiin teletolppia. Tarha vietti noin $1 \%$ :n kallistuksella navettarakennuksesta poispäin kulmassa olevaan saostuskaivoon, josta vedet johdettiin edelleen n. $10 \mathrm{~m}^{3}$ suuruiseen turve-hake-suodattimeen. Suodattimesta vedet johdettiin matalahkoon pelto-ojaan, jossa oli runsaasti kasvillisuutta.

Jyräbetonitarhan rakennekerrosten kustannusarvio oli $48 \mathrm{mk} / \mathrm{m}^{2}$. Kaikkiaan tarhan kustannusarvio oli $67 \mathrm{mk} / \mathrm{m}^{2}$. Suodattimen $\left(10 \mathrm{~m}^{3}\right)$ rakentamiskustannuksiksi arvioitiin $9000 \mathrm{mk}$ ilman tutkimuksesta aiheutuvia lisäkustannuksia.

\section{Tulokset ja tulosten tarkastelu \\ Käyttökokemuksia}

Ruukin maapohjaisessa ulkotarhassa puut ja muu kasvillisuus kärsivät huomattavia vahinkoja jo vuoden kestäneen tarhauksen jälkeen. Sonnit kuorivat kaikki isot koivut ja kuuset tyveltä. Männyistäkin 10-40 \% oli vuoden kuluttua tyveltä ympärikuorittuja. Maanpinta muuttui mullokselle nopeasti. Var- 
sinkin ne tarhan osat, joissa eläimet viettivät suurimman osan ajastaan, muuttuivat mutaisiksi syys- ja kevätvalunnan aikana.

Juvan maapohjainen kuorikkeella peitetty jaloittelutarha oli sorkkaystävällinen ja pitävä. Lehmät viihtyivät siinä paremmin kuin asfalttipohjaisessa tarhassa. Tarha-ala, $10 \mathrm{~m}^{2}: a ̈$ lehmää kohden, riitti hyvin. Kokeessa käytetyn kuorikkeen todettiin käyttöominaisuuksiensa puolesta olevan sopivaa maapohjaisen jaloittelutarhan pintamateriaaliksi. Kuorike oli tarpeeksi karkeaa, joten se läpäisi hyvin vettä ja kesti lehmien liikkumista. Vajaan vuoden käytössäoloaikana se oli hienontunut niin, että se voitiin levittää kynnettävälle nurmipellolle ilman kompostointia. Tällä hetkellä näyttää siltä, että kuorike pitää vaihtaa vähintään vuoden välein.

Asfalttipohjaisesta tarhasta oli helppo kerätä talteen lanta ja lantavedet, jolloin niitä ei päässyt hallitsemattomasti ympäristöön. Tarhan puhdistaminen onnistui traktorin etukuormaajalla ja tarhavedet kerättiin kaivoon. Haittapuoliksi kirjattiin pinnan liukkaus talvella, vaikka pohjaa hiekoitettiinkin. Tarha aiheutti lisätyötä, sillä se puhdistettiin säännöllisesti esim. kerran viikossa. Valumavesikaivojen jäätymisen takia sulamisvesiä pääsi tarhan ulkopuolelle.

\section{Ulkotarhasta aiheutunut kuormitus}

Pintamaan ravinnepitoisuudet kasvoivat jo ensimmäisen tarhaustalven aikana. Ennen tarhauksen aloittamista viljavuusfosforin pitoisuus oli $0-5 \mathrm{~cm}: n$ maakerroksessa $0,7-12,6 \mathrm{mg} \mathrm{kg}^{-1}$ (mediaani 5,2). Viljavuusfosforin pitoisuus kasvoi ensimmäisen tarhaustalven jälkeen 5,6-62,7 mg:aan kg-1 (mediaani 10,2) ja yhden vuoden jälkeen jo 5,2-133 mg:aan $\mathrm{kg}^{-1}$ (mediaani 28,8 ), mikä peltoviljelyssä vastaa viljavuusluokkaa hyvä tai korkea. Myös ammoniumtypen määrä maassa kasvoi 3-8 kg:sta ha ${ }^{-1} 13-190$ $\mathrm{kg}$ :aan ha ${ }^{-1}$ (mediaani $86 \mathrm{~kg} \mathrm{ha}^{-1}$ ). Tosin metsämaan alhainen $\mathrm{pH}$ edesauttoi sitä, että ammoniumtyppi ei nitrifioitunut helposti nitraattitypeksi. Kuitenkin pintamaan $\mathrm{NO}_{3}$-N-pitoisuus kasvoi $0,02-102$ mg:aan $\mathrm{kg}^{-1}$ (mediaani 8,1). Suurimmat $\mathrm{NO}_{3}$-N-pitoisuudet löytyivät katoksen ympäristöstä. Ennen kokeen aloittamista $60 \mathrm{~cm}: n$ paksuisessa maakerroksessa oli 0,2-2,0 $\mathrm{kg} \mathrm{NO}_{3}-\mathrm{N} \mathrm{ha}^{-1}$ (mediaani 0,3) ja vuoden kestäneen tarhauksen jälkeen jo $0,3-51 \mathrm{~kg} \mathrm{NO}_{3}-\mathrm{N} \mathrm{ha}^{-1}$ (mediaani 6,1).

Ensimmäisen talven jälkeen tarhasta tulleessa pintavalumavedessä oli liukoista fosforia $0,005-$ $0,665 \mathrm{mg} \mathrm{l}^{-1}$ ja kokonaisfosforia $0,082-1,047 \mathrm{mg} \mathrm{l}^{-1}$, mitkä vastasivat peltovalumavesien pitoisuuksia. Toisen talven jälkeen ravinnepitoisuudet edelleen kasvoivat kevään lumensulamisvesissä.

Taulukko 1. Pintavalunta, mm, ja sen mukana kulkeutuneet ravinnemäärät, kg ha-1, 14.4.2000-31.5.2001 Ruukin ulkotarhassa. $\mathbf{H j}$.= haihdutusjäännös.

\begin{tabular}{|c|c|c|c|c|c|c|c|}
\hline \multirow[b]{2}{*}{ Jakso } & \multirow{2}{*}{$\begin{array}{c}\text { Valunta } \\
\mathrm{mm}\end{array}$} & \multirow{2}{*}{$\mathrm{PO}_{4}-\mathrm{P}$} & \multirow[t]{2}{*}{ Kok-P } & \multirow{2}{*}{$\frac{\mathrm{NO}_{3}-\mathrm{N}}{\mathrm{kg} \mathrm{ha}^{-1}}$} & \multirow[t]{2}{*}{$\mathrm{NH}_{4}-\mathrm{N}$} & \multirow[t]{2}{*}{ Kok-N } & \multirow[t]{2}{*}{$\mathrm{Hj}}$. \\
\hline & & & & & & & \\
\hline $14.4 .-30.4 .2000$ & 90 & 0.270 & 0.48 & 0.02 & 0.7 & 1.7 & 130 \\
\hline 1.5.-15.5.2000 & 14 & 0.011 & 0.03 & 0.01 & 0.1 & 0.2 & 16 \\
\hline 19.6.-12.8.2000 & 17 & 0.003 & 0.01 & 0.00 & 0.1 & 0.2 & 52 \\
\hline 14.8.-24.12.2000 & 45 & 0.100 & 0.24 & 0.29 & 0.4 & 1.1 & 5 \\
\hline Yhteensä & 187 & 0.384 & 0.75 & 0.32 & 1.2 & 3.2 & 203 \\
\hline 6.4.-30.4.2001 & 26 & 0.470 & 0.67 & 0.09 & 0.9 & 1.9 & 54 \\
\hline 1.5.-31.5.2001 & 16 & 0.119 & 0.26 & 0.08 & 0.4 & 1.1 & 92 \\
\hline Yhteensä & 42 & 0.589 & 0.93 & 0.17 & 1.3 & 3.1 & 146 \\
\hline
\end{tabular}

\section{Jaloittelutarhoista aiheutunut kuormitus}

Kuorikkeen ja maapohjan läpi suotautuneet vedet olivat selkeästi puhtaampia kuin asfalttitarhan valumavedet sekä typen että fosforin osalta (taulukko 2). Kuoriketarhan vesissä fosforipitoisuudet olivat pääosin peltovalumavesien luokkaa. Kokonaisfosforista oli liukoisessa muodossa noin puolet. Nitraattitypen pitoisuudet olivat pieniä. Asfalttitarhassa ravinnepitoisuudet vaihtelivat hyvin laajalla skaalalla. Tämä selittyy valumavesimäärän vaihtelulla - suuret vesimäärät laimensivat varsinkin typpipitoisuuksia - sekä tarhassa valuntahetkellä olleella lantamäärällä.

Tarhoista tulleiden vesien märää ei pystytty mittaamaan luotettavasti, sillä asfalttitarhan pumppu toimi hyvin epävarmasti. Syynä tähän oli kaivoon mennyt lantaliete, joka pyrki tukkimaan pumpun. 
Taulukko 2. Jaloittelutarhojen valumavesinäytteiden ravinnepitoisuudet 6.4.-12.11.2001. $(\mathrm{COD}=$ kemiallinen hapenkulutus, $\mathbf{H j .}$ = haihdutusjäännös). 40 näytettä asfalttitarhasta ja 30 kuoriketarhasta.

\begin{tabular}{lllllll} 
& \multicolumn{3}{c}{ Asfalttitarha } & \multicolumn{3}{c}{ Kuoriketarha } \\
& Mediaani & Maksimi & Minimi & Mediaani & Maksimi & Minimi \\
\hline $\mathrm{PO}_{4}-\mathrm{P}(\mathrm{mg} / \mathrm{l})$ & 24,3 & 49,7 & 6,7 & 0,1 & 1,8 & 0,0 \\
$\mathrm{Kok} . \mathrm{P}(\mathrm{mg} / \mathrm{l})$ & 48,6 & 113 & 15,2 & 4,3 & 14,2 & 1,2 \\
$\mathrm{NO}_{3}-\mathrm{N}(\mathrm{mg} / \mathrm{l})$ & 0,07 & 1,24 & 0,02 & 0,01 & 0,88 & 0,0 \\
$\mathrm{NH}_{4}-\mathrm{N}(\mathrm{mg} / \mathrm{l})$ & 77,9 & 486 & 1,9 & 29,2 & 47,2 & 6,2 \\
$\mathrm{Kok}-\mathrm{N}(\mathrm{mg} / \mathrm{l})$ & 179 & 907 & 16,2 & 43,3 & 84,1 & 6,7 \\
$\mathrm{COD}(\mathrm{mg} / \mathrm{l})$ & 3000 & 11300 & 544 & 2900 & 4900 & 1900 \\
$\mathrm{Hj} .(\mathrm{g} / \mathrm{l})$ & 3,4 & 9,6 & 0,6 & 2,9 & 4,3 & 2,0 \\
$\mathrm{pH}$ & 7,7 & 8,3 & 7,2 & 6,0 & 8,4 & 5,4 \\
\hline
\end{tabular}

Myös mikrobipitoisuudet olivat asfalttitarhan vesissä suuria: fekaalisia koleja 700 000-120.000 000 kpl/100 ml ja DNA-kolifaageja 100 000-4.000 000 kpl/100 ml. Nämä vastasivat lietelannan tai asumajäteveden mikrobipitoisuuksia. Kuoriketarhasta suotautuneiden vesistä mitattiin syyskuussa 2001 fekaalisia koleja 130000 kpl/100 ml ja DNA-kolifaageja 18000 kpl/100 ml. Kuoriketarhankaan vedet eivät täyttäneet EU:n uimavesivaatimuksia. Ulkotarhan bakteeripitoisuudet on esitetty taulukossa 3.

Taulukko 3. Ulostesaastumista kuvaavien mikrobien määrät, kpl/100 ml, ulkotarhan pintavalumavesissä.

\begin{tabular}{|lccccc|}
\hline & $\mathrm{A}$ & 8.10 .01 & 16.10 .01 & 30.10 .01 & 5.11 .01 \\
\hline $\begin{array}{l}\text { Fekaaliset koliformiset } \\
\text { bakteerit }\left(44,5^{\circ} \mathrm{C} / 21 \mathrm{~h}\right)\end{array}$ & $<500$ & 24 & 640 & 170 & 850 \\
\hline $\begin{array}{l}\text { Koliformiset bakteerit } \\
\left(37^{\circ} \mathrm{C} / 24 \mathrm{~h}\right)\end{array}$ & $<10000$ & 3200 & 4300 & 2200 & 1200 \\
\hline $\begin{array}{l}\text { Fekaaliset streptokokit } \\
\left(37^{\circ} \mathrm{C} / 48 \mathrm{~h}\right)\end{array}$ & $<200$ & 7 & 50 & 8 & 6 \\
\hline $\begin{array}{l}\text { Sulfiittia pelkistävät } \\
\text { klostridit }\left(37^{\circ} \mathrm{C} / 44 \mathrm{~h}\right)\end{array}$ & & 50 & 34 & 54 & 40 \\
\hline
\end{tabular}

$\mathrm{A}=$ Raja-arvo EU-uimavesille.

\section{Johtopäätökset}

Tarhakasvatuksen investointikustannukset riippuvat tarhan varustelusta sekä sijainnista suhteessa talouskeskukseen. Jos veden ja sähkön saanti alueelle onnistuu ilman merkittäviä kustannuksia ja eläinten säänsuojana voidaan käyttää tilalla jo olemassa olevia rakennuksia (esim. vanhat heinäladot), muodostuu suurimmaksi investoinniksi aitaus.

Jaloittelutarhan koko $10 \mathrm{~m}^{2} /$ eläin oli riittävä. Vapaassa ulkoilussa riitti vähempikin tila, koska kaikki eläimet eivät olleet yhtä aikaa ulkona. Aitakorkeus oli yleensä riittämätön tarhoissa. Eläimet hyppivät aitojen yli talvella, kun tarhaan oli kertynyt lunta. Sopiva aitakorkeus on 150-160 cm.

Hyvin suunnitellut ja rakennetut tarhat toimivat suurimman osan vuodesta. Talvella ja keväällä kiinteäpohjaisten tarhojen käytössä oli ongelmia liukkauden ja jäätymisen takia. Kiinteän pohjan tulee olla riittävän kalteva, jotta sadevesi valuu nopeasti pois, eikä jää liuottamaan lannasta ravinteita. Toisaalta tarha ei saa olla liian kalteva, etteivät eläimet liukastele sateen tai jään liukastamalla pinnalla. Kylmäpihattojen käytäville maksimikaltevuus nautaeläinten liikkumisen kannalta ja jalkarasitukset huomioon ottaen on n. $8 \%$ (MMM-RMO C 1.2.2).

Maapohjaisissa tarhoissa fosforia kertyi maan pintakerrokseen, josta sitä voi kulkeutua pintavalunnan mukana vesistöihin. Typpeä saattoi huuhtoutua alaspäin hyvin läpäisevässä moreenimaassa. Kiinteäpohjaisista tarhoista vedet kerättiin kaivoon. Talvella kaivon jäätyminen aiheutti ongelmia.

\section{Kirjallisuus}

Manninen, M. (toim.) 2001. Hyvinvoivat naudat puhtaassa ympäristössä -loppuraportti. ulkokasvatustarhat. Jokioinen 2001. Maa- ja metsätalousministeriö Maatilatalouden kehittämisrahasto, Maa- ja elintarviketalouden tutkimuskeskus.

MMM-RMO C 1.2.2. Maa- ja metsätalousministeriön rakentamismääräykset ja -ohjeet. Kotieläinrakennukset, Lihanautarakennukset. 